\title{
Presence of oestrogen receptor type $\beta$ in human retina
}

Carine Munaut, Vincent Lambert, Agnès Noël, Francis Frankenne, Manuel Deprez, Jean-Michel Foidart, Jean-Marie Rakic

\begin{abstract}
Backgroundlaims-Recent studies have demonstrated the existence of two oestrogen receptor subtypes $\alpha(\mathrm{OR} \alpha)$ and $\beta$ (OR $\beta)$ with significant differences of expression among organs. Since important pathologies of human eye could be linked to hormonal status, the expression of OR $\beta$ in ocular posterior segment was sought. Methods-Immunohistochemical localisation of OR $\beta$ and $O R \alpha$ protein and detection of OR mRNAs by reverse transcription-polymerase chain reaction (RT-PCR) were performed in macular and extramacular regions of the retina and in the choroid on male and female donors eyes.

Results-OR $\beta$ protein was localised in the ganglion cell layer and in the choroid. At the transcriptional level, mRNA for OR $\beta$ and for OR $\alpha$ were both present. Local differences in the expression level were observed, however, suggesting the possibility of variation in the ratio of OR $\alpha v$ ORß.

Conclusions-The coexistence of two oestrogen receptor subtypes in the human ocular posterior segment raises acute questions about their potential physiological role, but offers a perspective for preferential targeting of a specific receptor subtype.

(Br f Ophthalmol 2001;85:877-882)
\end{abstract}

Laboratory of Tumor and Development Biology, University of Liège, Pathology Tower (B23), Sart-Tilman, B-4000 Liège, Belgium C Munaut

V Lambert

A Noël

F Frankenne

J-M Foidart

Department of Neuropathology M Deprez

Department of Ophthalmology, University Hospital,

Sart-Tilman, B-4000

Liège, Belgium

J-M Rakic

Correspondence to: C Munaut

c.munaut@ulg.ac.be

Accepted for publication 13 February 2001
Oestrogens are steroid hormones traditionally connected with either reproductive system or with bone tissue and cardiovascular system. Their receptors are members of the nuclear receptor superfamily (including among others, receptors for steroids, vitamin $\mathrm{D}$, and retinoic acid) and they mediate most of the known effects of oestrogens. These intracellular proteins function as ligand activated transcription factors regulating gene transcription.

A new type of oestrogen receptor, OR $\beta$ has recently been cloned ${ }^{1}$ and subsequently its mRNA was found in various organs of male and in different areas of the brain, while OR $\alpha$ is found mainly in most female organs. The finding of a second receptor having different tissue distribution and molecular characteristics is obviously raising a question about the interpretation of oestrogens actions in different organs.

The roles of oestrogens in ophthalmic pathology have been mainly evaluated in the anterior segment. Epidemiological and experimental data suggest a protective effect of oestrogens in age related cataractogenesis. ${ }^{2-4}$ Tear function is influenced by sex hormones, and the onset of dry eye is very common during the menopause. ${ }^{5}$ The situation in the retina is more controversial. Different epidemiological studies reported a protective effect of oestrogen replacement therapy on the development of neovascular age related macular degeneration (AMD) ${ }^{67}$ while others failed to demonstrate a significant sex difference in the frequency of the disease. ${ }^{8}$ The reasons for these discordant findings are unknown, but could partly be explained by the considerable differences among clinically used oestrogens for their binding affinities on their receptor subtypes. ${ }^{9}$ Kobayashi et al convincingly demonstrated the presence of an oestrogen receptor in the rat and bovine retina, without differentiating $\mathrm{OR} \alpha$ and $\mathrm{OR} \beta .{ }^{10}$ In the human eye, a recent report suggested the presence of $\mathrm{OR} \alpha$ in the young female retina. ${ }^{11}$

As the retina obviously shares common biological features with the brain, we hypothesised that OR $\beta$ could also be expressed in the retina and/or in the choroid. We report here that the $\beta$ type oestrogen receptor is present in human male and female ocular posterior segments, with some regional differences in the level of mRNA expression.

\section{Materials and methods}

TISSUE COLLECTION

Human male and female donor eyes (eight males and five females) with a limited postmortem enucleation time (1-15 hours) were collected from the Cornea Bank, University of Liège, Belgium. Mean age was 65 years (range 46-82). After removal of the anterior segment structures, $5 \mathrm{~mm}$ diameter punches were made in the macular region and in the peripheral retina. Neural retina was then separated from the retinal pigment epithelium and from the choroid (RPE-choroid complex) and tissues were stored at $-80^{\circ} \mathrm{C}$. Alternatively, posterior segments were fixed in $4 \%$ formalin, dehydrated, and embedded in paraffin.

The mean blood testosterone level in males (measured post mortem by radioimmunoassay, Immunotech) was $0.84 \mu \mathrm{g} / 1$ (range $0.11-2.38$ ) and the mean oestrogen level (Immunotech) in females was $148 \mathrm{ng} / 1$ (range 32-303).

IMMUNOCYTOCHEMICAL LOCALISATION OF OR $\beta$ Frozen sections of $5 \mu \mathrm{m}$ were fixed 5 minutes in acetone at room temperature, air dried, and covered for 1 hour with 3\% normal goat serum. Then, rabbit anti-human oestrogen $\alpha$ or $\beta$ receptor (Santa Cruz Biotechnology, CA, USA) 
diluted 1/25 was applied for 1 hour, sections were rinsed in TRIS/ $\mathrm{HCl} \mathrm{pH} 7.4$ saline, and covered with one drop of EnVision (Dako, ready to use goat anti-rabbit peroxidase conjugated antibody) for 30 minutes. After rinsing in TRIS/ $\mathrm{HCl}$, one drop of AEC+ (Dako, 3-amino-9ethylcarbazole) was added. Sections were washed in water, counterstained for 1 minute in haematoxylin, and mounted in Aquamount. Deparaffinised sections were similarly treated excepting for a preliminary microwave step (350 $\mathrm{W}$, four times for 5 minutes in $10 \mathrm{mM}$ sodium citrate buffer, $\mathrm{pH}$ 6.0) to unmask antigenic sites. Negative controls were obtained by omitting the
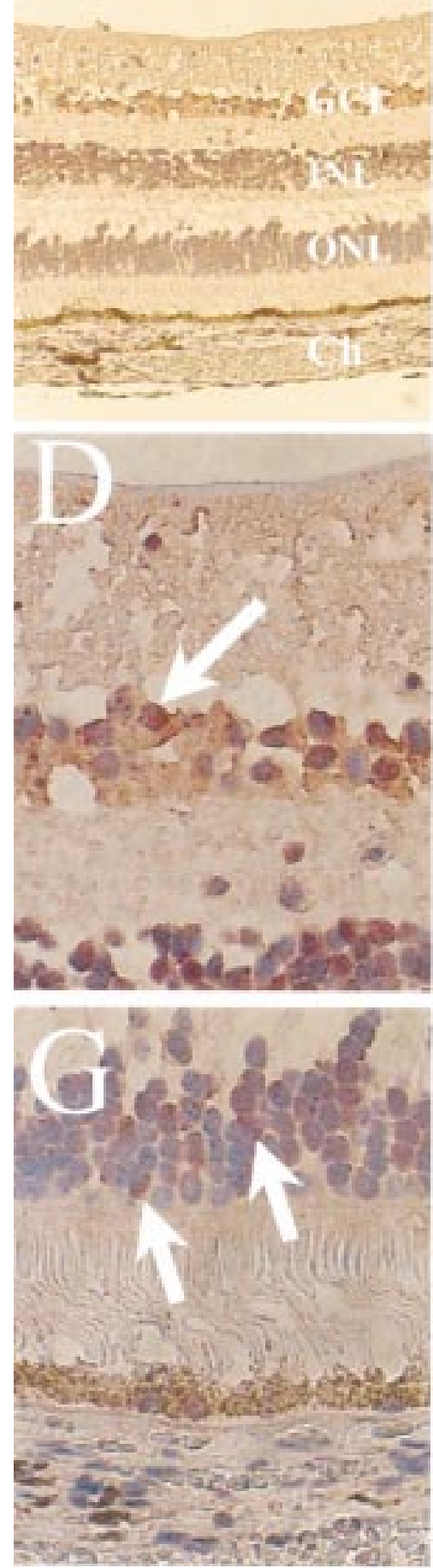
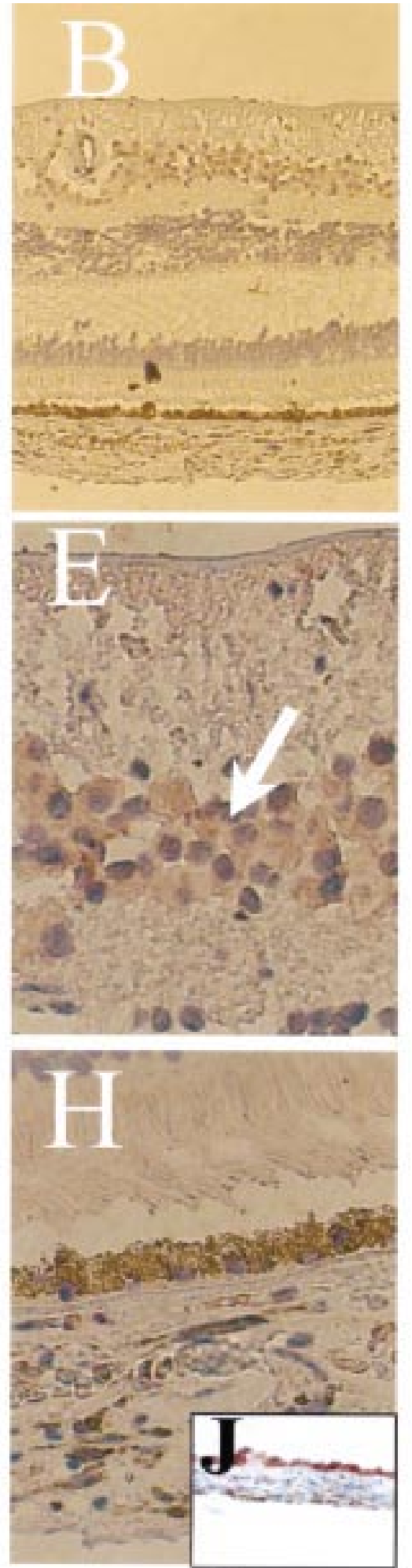
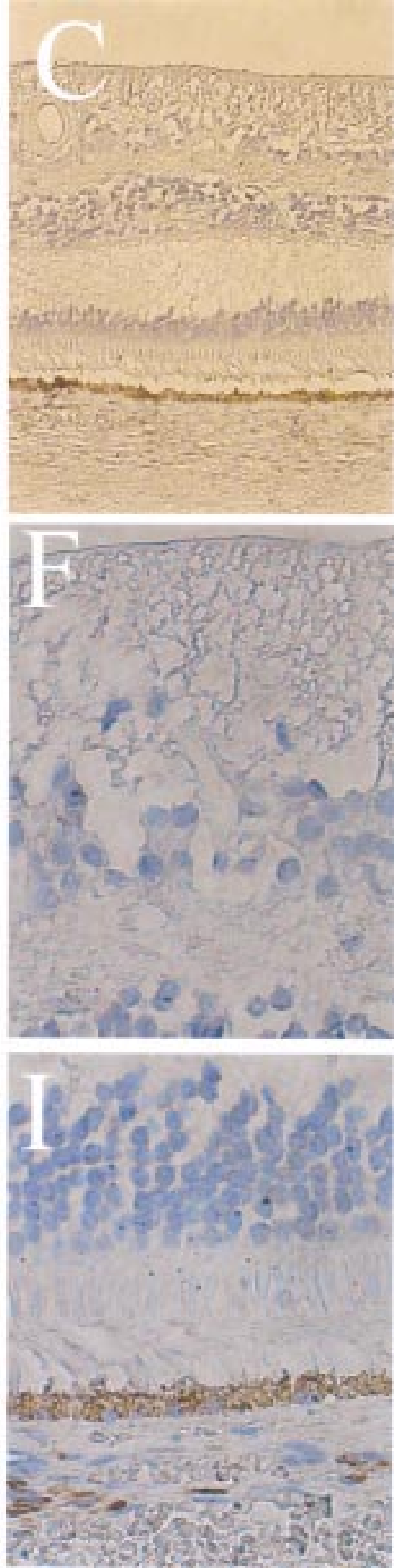

Figure 1 Immunolocalisation of $\mathrm{ORa}(A, D, G)$ and $\mathrm{OR} \beta(B, E, H)$ and negative controls $(C, F, I)$ on paraffin sections of ocular posterior segment at low magnification $(\times 100, A, B, C)$ or higher magnification $(\times 400)$ focused either on ganglion cell layer $(D, E, F)$, on the choroid-RPE complex $(G, H, I)$, or selectively on the RPE (f). Note the staining of ORa (arrows) in all nuclear lavers $(A)$ and the concentration of OR $\beta$ (arrows) in ganglion cell layer (E) and in choroidal structures $(H) . C h=$ choroid; $O N L=$ outer nuclear layer; INL = inner nuclear layer; $G C L=$ ganglion cell layer. 
Eye

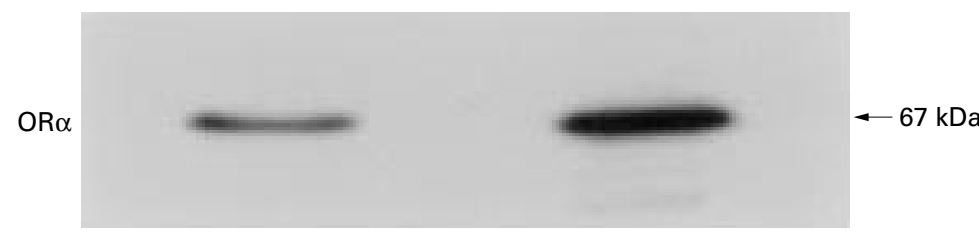

HT1080

Eye

Testis

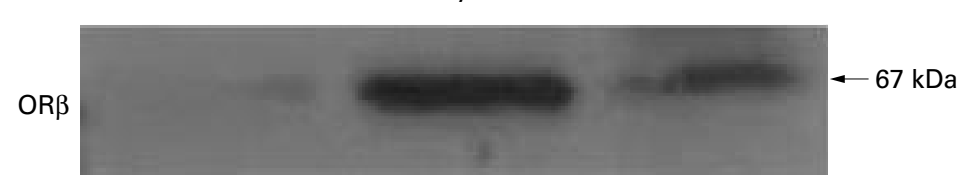

Figure 2 Human retina contained a band of oestrogen receptor $\alpha$ and $\beta$ (relative molecular mass of $67 \mathrm{kDa}$ ). Testis was used as a positive control, and the HT1080 cell line was negative.
(Perkin Elmer) and three pairs of primers (Gibco BRL Life Technologies) (sense: 5'GTTTCCCCCCACTCAACAGCGT-3' and reverse: 5'-ACTTCCCTTGTCATTGGTAC TGGC-3' for OR $\alpha$ mRNA, ${ }^{12}$ sense: 5'TTCCCAGCAATGTCACTAACT-3' and reverse: 5'-CTCTTTGAACCTGGACCA GTA-3' for OR $\beta$ mRNA, ${ }^{13}$ and sense: 5'GTTCACCCACTAATAGGGAACGTGA-3' and reverse: 5'-GGATTCTGACTTAGAG GCGTTCAGT-3' for $28 \mathrm{~S}$ rRNA $^{14}$ ). Reverse transcription was performed at $70^{\circ} \mathrm{C}$ for 15 minutes, followed by 2 minutes' incubation at $95^{\circ} \mathrm{C}$ for denaturation of RNA-DNA heteroduplexes. Amplification started by 15 seconds at $94^{\circ} \mathrm{C}, 20$ seconds at $58^{\circ} \mathrm{C}$, and 15 seconds at $72^{\circ} \mathrm{C}$ ( 35 cycles for OR $\alpha$ and OR $\beta$ and 19 cycles for 28S) and terminated by 2 minutes at $72^{\circ} \mathrm{C}$. RT-PCR products were resolved on $10 \%$ acrylamide gels and analysed using a Fluor-S MultiImager (BioRad) after staining with Gelstar dye (FMC BioProducts).

primary antibody, while for positive controls, uterine tissue known to express oestrogen $\beta$ was used (data not shown).

WESTERN BLOT ANALYSIS

Analyses of $\mathrm{OR} \alpha$ and $\mathrm{OR} \beta$ protein expression were performed from $5 \mathrm{~mm}$ punches made in the macular region, from testis and HT1080.

Protein extracts were prepared from the cell pellet in RIPA buffer ( $50 \mathrm{mM}$ TRIS (pH 7.4), $150 \mathrm{mM} \mathrm{NaCl}, 1 \%$ Igepal (v/v), 1\% sodium deoxycholate (w/v), $5 \mathrm{mM}$ iodoacetamide, $0.1 \%$ SDS $(\mathrm{w} / \mathrm{v}))$ containing protease inhibitors (1 $\mathrm{mM}$ phenylmethylsulphonyl fluoride, $10 \mu \mathrm{g} / \mathrm{ml}$ leupeptin and $10 \mu \mathrm{g} / \mathrm{ml}$ aprotinin).

For HT1080, total extracts were performed by scraping, in RIPA buffer. Protein concentration was determined with the DC protein assay (BioRad, Richmond, CA, USA).

Samples $(20 \mu \mathrm{g}$ for OR- $\alpha$ and OR- $\beta$ analyses) were mixed with $1 / 5$ sample buffer (0.31 M TRIS (pH 6.8), 10\% SDS (w/v), 25\% glycerol ( $/ \mathrm{v}), 12.5 \% \beta$ mercaptoethanol (v/v), and $0.125 \%$ bromophenol blue $(\mathrm{w} / \mathrm{v})$ ) and boiled for 5 minutes. They were then separated on $7.5 \%$ and $12 \%$ SDS-PAGE gels for OR $\alpha$ and OR $\beta$ analyses respectively and transferred to a PVDF filter (NEN, Boston, MA, USA). The membranes were then blocked with $5 \%$ milk (w/v), $0.1 \%$ Tween $20(\mathrm{w} / \mathrm{v})$ in phosphate buffered saline (PBS) for 2 hours before exposure to the primary antibody overnight at $4^{\circ} \mathrm{C}$ : rabbit anti-human oestrogen $\alpha$ or $\beta$ receptor (Santa Cruz Biotechnology, CA, USA). The filters were then incubated either with a horseradish peroxidase conjugated swine anti-rabbit or goat anti-mouse antibody (Dako). Signals were detected with an enhanced chemiluminescence (ECL) kit (NEN, Boston, MA, USA).

DETECTION OF OR $\alpha$ AND OR $\beta$ BY RT-PCR

Total RNA from $5 \mathrm{~mm}$ punches were extracted using RNeasyMini Kit (Qiagen) as described by the manufacturer. $28 \mathrm{~S}$ rRNA, OR $\alpha$ and OR $\beta$ mRNA were measured in $10 \mathrm{ng}$ aliquots of total RNA using the GeneAmp Thermostable $r$ th reverse transcriptase RNA-PCR kit

\section{Results}

OR IMMUNOLOCALISATION ON POSTERIOR SEGMENT SECTIONS

Cytoplasmic and nuclear staining with the antioestrogen receptor $\beta$ antibody were mainly observed in the ganglion cell layer of the retina (Fig 1B, E, H). Immunolocalisation in the choroid was mild and inconsistent. The staining was similar in tissues of both sexes and its localisation was the same on frozen (not shown) and on paraffin sections. No staining could be observed in the absence of the primary antibody (Fig 1C, F, I). Immunolocalisation of receptor $\alpha$ antibody was more widespread in the neural retina (Fig 1A, D, G) and its localisation correlated with previously performed analysis on human tissue, with more intensity in the ganglion cell layer. ${ }^{11}$

WESTERN BLOT ANALYSIS

The presence of oestrogen receptors $\beta$ and $\alpha$ in the human retina was confirmed by western blot analysis with the appropriate antioestrogen receptor antibody (Fig 2). Specimens contained a band of oestrogen receptor protein at a relative molecular mass of $67 \mathrm{kDa}$. The HT1080 cell line was used as a negative control in which no $67 \mathrm{kDa}$ band was observed. A band was present in the testis (positive control).

OR MRNA EXPRESSION IN THE POSTERIOR SEGMENT The primer specificity was checked using total RNA isolated from human testis and from endometrial Ishikawa cells and breast adenocarcinoma MCF-7 cells (data not shown). OR $\alpha$ and OR $\beta$ primers amplified a $234 \mathrm{bp}$ and a $258 \mathrm{bp}$ fragment, respectively. $\operatorname{OR} \alpha$ and $\operatorname{OR} \beta$ mRNA expression was detected in ocular tissues from patients of different age and sex, regardless of the region of the sample (inside or outside the macula) (Fig 3). The expression of OR $\beta$ mRNA was relatively constant between different donors, while there was more variation with $\mathrm{OR} \alpha$. This variation was also total RNA selectively extracted from neural observed when RT-PCR was performed using 


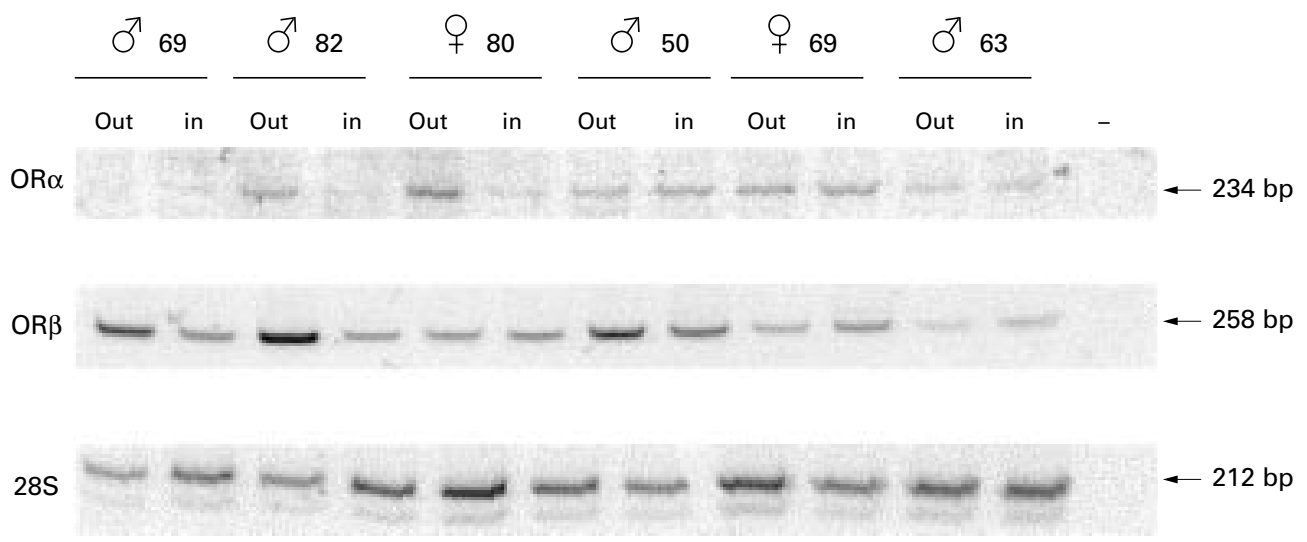

Figure 3 Representative example of $O R a$ and $O R \beta m R N A$ expression in the eye of various sex donors (age is given in years with sex symbol). Total RNA (approximately $10 \mathrm{ng}$ ) from the macular region (in) or from the peripheral retina (out) were submitted to RT-PCR as described in Materials and methods. The $28 S$ rRNA (lower panel) is used to assess the total amount of RNA loaded.

retina and the choroid region (Fig 4). Both receptor subtypes $\mathrm{mRNA}$ were detected in the RPE-choroid complex, but OR $\alpha$ was unequally distributed between the retina and the RPEchoroid (Fig 4).

\section{Discussion}

In this report, we demonstrate the presence of OR $\beta$ in human male and female ocular posterior segment by immunohistochemistry, western blot analysis, and RT-PCR. At the transcriptional level, while the expression of OR $\beta$ was relatively constant, much more variability between different specimens was observed for $\mathrm{OR} \alpha$. This suggests the possibility of variation in the ratio of OR $\alpha v$ OR $\beta$ mRNA expression.

The precise effects of oestrogens on the retina are largely unexplored and a detailed discussion about their potential action in retinal pathology is obviously speculative even

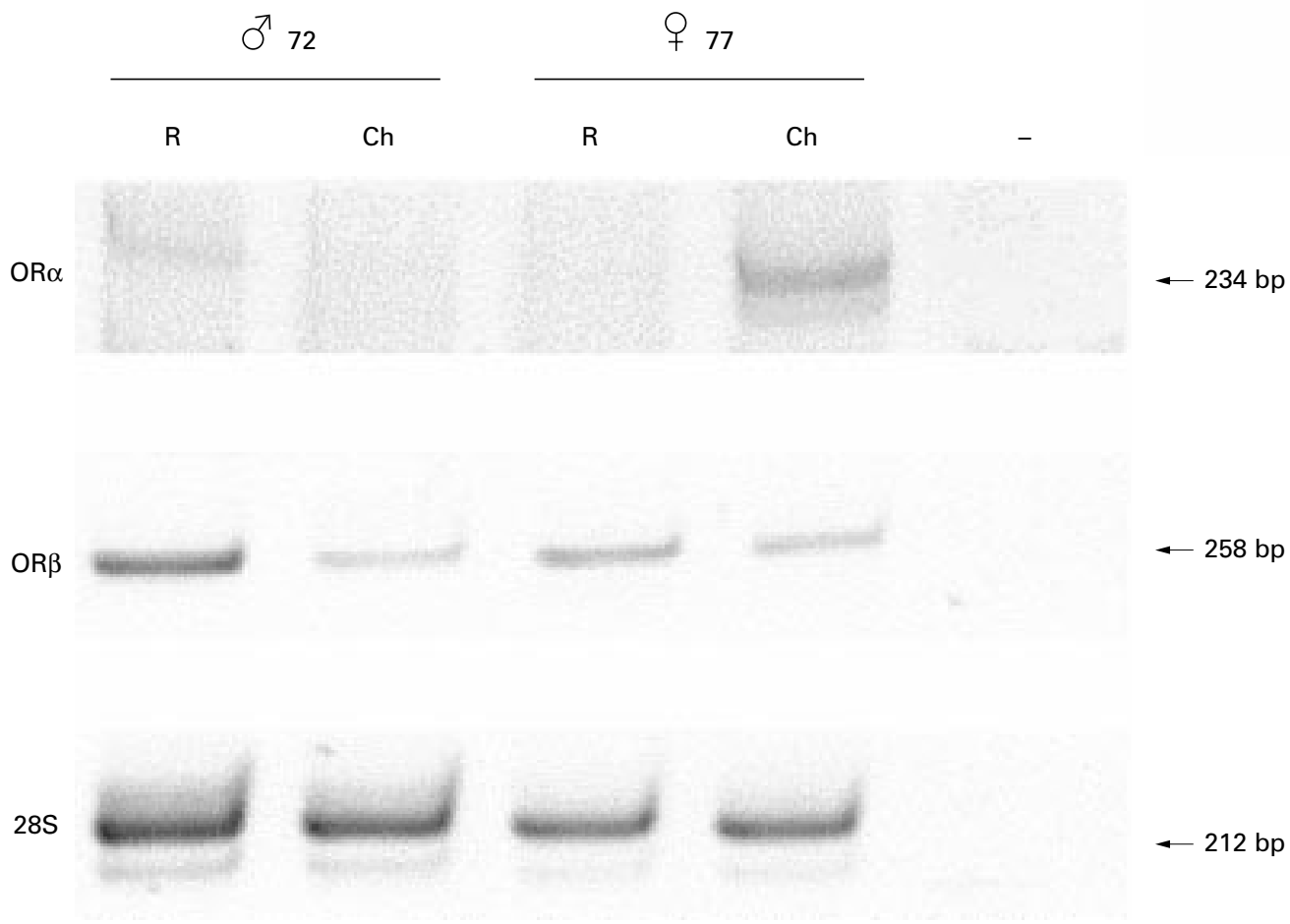

Figure $4 \quad O R a$ and OR $\beta m R N A$ expression in human retinas $(R)$ and choroidal $(C h)$ regions of a representative couple of male and female donors. RT-PCR was performed as described in Materials and methods. The 28S rRNA is used to assess the total amount of RNA loaded. 
if some epidemiological data suggest a protective effect.

Nevertheless, our results contribute to explain, at least partly, the beneficial effects observed in retinal pathology with genistein treatment. Genistein is a naturally occurring phyto-oestrogen with a 20-fold affinity difference for OR $\beta v$ OR $\alpha{ }^{15}$ Recent studies have focused on the role of phyto-oestrogens on angiogenesis and tumour development. ${ }^{16}$ Genistein in vitro inhibits the proliferation of brain derived endothelial cells. ${ }^{17}$ Oestradiol $17-\beta$ is able to completely inhibit microvessels growth from explants of rat aorta embedded in collagen gel. ${ }^{18}$ Genistein effects described on retinal degeneration after ischaemia reperfusion in rat $^{19}$ or on experimental choroidal regeneration ${ }^{20}$ were attributed to its inhibitory action on tyrosine kinases. Tyrosine kinase inhibition requires rather high local concentration of genistein $(>10 \mu \mathrm{M})$ whereas a $0.1 \mu \mathrm{M}$ concentration is sufficient to exert an OR mediated effects. ${ }^{21}$ In female rats receiving dietary genistein in high amounts (daily dose of $20 \mathrm{mg} / \mathrm{kg}$ of body weight), the concentration in serum was only $2.2 \mu \mathrm{M} .{ }^{22}$ In a rat model of vascular endothelial injury associated with smooth muscle cell proliferation, a vasculoprotective effect of genistein without effect on the reproductive system was demonstrated by preferential targeting to OR $\beta$. This observation was explained by the predominance of the OR $\beta$ subtype in the vascular wall, with a $>40$-fold upregulation of OR $\beta$ expression after injury, while $\mathrm{OR} \alpha$ expression remained unchanged. ${ }^{23}$

Increasing experimental evidence demonstrate that oestrogens are neuroprotective ${ }^{2425}$ and that oestrogen replacement therapy may contribute to the prevention of, or even delay the onset of, Alzheimer's disease. ${ }^{26}$ In the eye, macular degeneration has been associated with early menopause. ${ }^{27}$ Precise biological mechanisms of oestrogen action on the retina still remain to be elucidated, but it is tempting to assume that one of the ways by which oestrogen could influence retinal biology is through RPE function. Relatively few genes are proved to be under the control of ORs. Among these is cathepsin $\mathrm{D}$, an aspartic protease highly expressed in human retinal pigment epithelial lysosomes with transcription regulated by oestrogen. ${ }^{28}$ Experimental impairment of cathepsin D results in accumulation of rod outer segment debris in the RPE. ${ }^{29}$ Another possibility would be the systemic or local regulation of apolipoprotein E (Apo E) metabolism. Apo $\mathrm{E}$ and its alleles (apoE2, apoE3, apoE4) are believed to play a part in cardiovascular disease, ${ }^{30}$ Alzheimer's disease, ${ }^{31}$ and in AMD. ${ }^{32}$ Mice on hypercholesterolic $\operatorname{diet}^{33}$ or deficient for $a p o E^{34}$ develop ultrastructural changes in Bruch's membrane similar to human basal linear deposits. Drusen, the hallmark of $\mathrm{AMD}$, share some major components with atherosclerotic plaques, including among others apoE. ${ }^{35}$ After brain injury, apoE is increased in areas of synaptic remodelling, and oestrogen increase apoE mRNA in astrocytes and microglia. ${ }^{36}$ Importantly, it has been shown that oestrogen prevent atherosclerosis in apoE deficient male mice. ${ }^{37}$

Finally, our observations suggest that under certain circumstances, the OR $\beta / \mathrm{OR} \alpha$ expression ratio could vary in the eye. This provides a mechanism by which oestrogen could exert different effects on the same cell type. Indeed, it has recently been demonstrated in an experimental model using transient transfection that OR $\alpha$ and OR $\beta$, when complexed with oestrogen, were signalling in opposite ways (turning on/off gene transcription) from an AP1 transcription site. ${ }^{38}$

Additional experimental and epidemiological studies about the roles of oestrogens in normal and diseased retina are obviously mandatory. The demonstration of two different receptor subtypes raises a perspective for preferential targeting.

Proprietary interest category: Nil

This study was supported by grants from Les Amis des Aveugles (Ghlin), the Fondation Léon Frédéricq, University of Liège, the Fonds d'Investissements de Recherche Scientifique, CHU, Liège, the CGER-Assurances all from Belgium. AN is a $\mathrm{CHU}$, Liege, the CGER-Assurances all from Belgium. AN is a
research senior associate and CM is a research associate from research senior associate and CM is a research associate from
the National Fund for Scientific Research (FNRS), Belgium.

The first two authors contributed equally to this paper.

1 Kuiper GG, Enmark E, Pelto-Huikko M, et al. Cloning of a novel receptor expressed in rat prostate and ovary. Proc Natl Acad Sci USA 1996;93:5925-30.

2 Bigsby RM, Cardenas H, Caperell-Grant A, et al. Protective effects of estrogen in a rat model of age-related cataracts. effects of estrogen in a rat model of age-retat
Proc Natl Acad Sci USA 1999;96:9328-32.

3 Benitez del Castillo JM, del Rio T, Garcia-Sanchez J. Effects of estrogen use on lens transmittance in postmenopausal women. Ophthalmology 1997;104:970-3

4 Cumming RG, Mitchell P. Hormone replacement therapy, reproductive factors, and cataract. The Blue Mountains Eye Study. Am f Epidemiol 1997;145:242-9.

5 Mathers WD, Stovall D, Lane JA, et al. Menopause and tear function: the influence of prolactin and sex hormones on human tear production. Cornea 1998;17:353-8.

6 The Eye Disease Case-Control Study Group. Risk factors for neovascular age-related macular degeneration. Arch Ophthalmol 1992;110:1701-8.

7 Smith W, Mitchell P, Wang JJ. Gender, oestrogen, hormone replacement and age-related macular degeneration: results from the Blue Mountains Eye Study. Aust NZ F Ophthalmol 1997;25(Suppl 1):S13-15.

8 Berger JW, Fine SL, Maguire MG. Age-related macular Berger JW, Fine SL, Maguire MG. Age-related macular
degeneration. In: Age-related macular degeneration. St Louis: degeneration. In: $A g$

9 Dubey RK, Jackson EK, Gillespie DG, et al. Clinically used estrogens differentially inhibit human aortic smooth muscle cell growth and mitogen-activated protein kinas activity. Arterioscler Thromb Vasc Biol 2000;20:964-72.

10 Kobayashi K, Kobayashi H, Ueda M, et al. Estrogen receptor expression in bovine and rat retinas. Invest Ophthalmol Vis Sci 1998;39:2105-10.

11 Ogueta SB, Schwartz SD, Yamashita CK, et al. Estrogen receptor in the human eye: influence of gender and age on
gene expression. Invest Ophthalmol Vis Sci 1999;40:190611.

12 Greene GL, Gilna P, Waterfield M, et al. Sequence and expression of human estrogen receptor complementary DNA. Science 1986;231:1150-4

13 Ogawa S, Inoue S, Watanabe $\mathrm{T}$, et al. The complete primary structure of human estrogen receptor beta (hER beta) and its heterodimerization with ER alpha in vivo and in vitro. Biochem Biophys Res Commun 1998;243:122-6.

14 Gonzalez IL, Gorski JL, Campen TJ, et al. Variation among human 28 S ribosomal RNA genes. Proc Natl Acad Sci USA 1985;82:7666-70.

15 Kuiper GG, Lemmen JG, Carlsson B, et al. Interaction of estrogenic chemicals and phytoestrogens with estrogen receptor beta. Endocrinology 1998;139:4252-63.

16 Fotsis T, Pepper MS, Montesano R, et al. Phytoestrogens and inhibition of angiogenesis. Bailliere's Clin Endocrinol Metab 1998;12:649-66.

17 Fotsis T, Pepper M, Adlercreutz H, et al. Genistein, a dietary-derived inhibitor of in vitro angiogenesis. Proc Natl Acad Sci USA 1993;90:2690-4.

18 Jaggers DC, Collins WP, Milligan SR. Potent inhibitory effects of steroids in an in vitro model of angiogenesis. $\mathcal{F}$ Endocrinol 1996;150:457-64.

19 Hayashi A, Weinberger AW, Kim HC, et al. Genistein, a protein tyrosine kinase inhibitor, ameliorates retinal degeneration after ischemia-reperfusion injury in rat. Invest Ophthalmol Vis Sci 1997;38:1193-202.

20 Majji AB, Hayashi A, Kim HC, et al. Inhibition of choriocapillaris regeneration with genistein. Invest Ophthalmol Vis Sci 1999;40:1477-86. 
21 Makela S, Davis VL, Tally WC, et al. Dietary estrogens act through estrogen receptor-mediated processes and show no antiestrogenicity in cultured breast cancer cells. Environ

22 Santell RC, Chang YC, Nair MG, et al. Dietary genistein exerts estrogenic effects upon the uterus, mammary gland and the hypothalamic/pituitary axis in rats. $\mathcal{F}$ Nut 1997;127:263-9.

23 Makela S, Savolainen H, Aavik E, et al. Differentiation between vasculoprotective and uterotrophic effects of ligands with different binding affinities to estrogen receptors alpha and beta. Proc Natl Acad Sci USA 1999;96: 7077-82.

24 Behl C, Widmann M, Trapp T, et al. 17-Beta estradiol protects neurons from oxidative stress-induced cell death in vitro. Biochem Biophys Res Commun 1995;216:473-82.

25 Hawk T, Zhang YQ, Rajakumar G, et al. Testosterone increases and estradiol decreases middle cerebral artery occlusion lesion size in male rats. Brain Res 1998;796:2968 .

26 Tang MX, Jacobs D, Stern Y, et al. Effect of oestrogen during menopause on risk and age at onset of Alzheimer's disin ane

27 Vingerling JR, Dielemans I, Witteman JC, et al. Macular degeneration and early menopause: a case-control study. BMF 1995;310:1570-1

28 Cavaney-Brooker DM, Rakoczy PE. Cloning of a majo human retinal pigment epithelial lysosomal aspartic protease and mapping its transcriptional start sites. Cur Eye Res 1999; 18:310-18.

29 Rakoczy EP, Zhang D, Lay M, et al. Accelerated rod outer segment (ROS) derived debris accumulation linked to the production of enzymatically inactive cathepsin D. Invest Ophthalmol Vis Sci 2000;41:(Abstract 2190).
30 Knouff C, Hinsdale ME, Mezdour H, et al. Apo E structure determines VLDL clearance and atherosclerosis risk in mice. F Clin Invest 1999;103:1579-86.

31 Corder EH, Saunders AM, Strittmatter WJ, et al. Gene dose of apolipoprotein E type 4 allele and the risk of Alzheimer's disease in late onset families. Science 1993;261:921-3.

32 Klaver CC, Kliffen M, van Duijn CM, et al. Genetic association of apolipoprotein $\mathrm{E}$ with age-related macular degenration. Am f Hum Genet 1998;63:200-6.

33 Sharara N, Dithmar S, Le NA, et al. Accumulation of deposits in Bruch's membrane in mice correlate with age and high-fat diet. Invest Ophthalmol Vis Sci 2000;41: (Abstract 593).

34 Brown S, Dithmar S, Curcio CA, et al. Ultrastructural changes in Bruch's membrane of apolipoprotein E-deficient mice. Invest Ophthalmol Vis Sci 2000; 41(Abstract 594).

35 Mullins RF, Russell SR, Anderson DH, et al. Drusen associated with aging and age-related macular degeneration contain proteins common to extracellular deposits associated with atherosclerosis, elastosis, amyloidosis, and dense deposit disease. FASEB 7 2000;14:835-46.

36 Stone DJ, Rozovsky I, Morgan TE, et al. Astrocytes and microglia respond to estrogen with increased apoE mRNA in vivo and in vitro. Exp Neurol 1997;143:313-18.

37 Bourassa PA, Milos PM, Gaynor BJ, et al. Estrogen reduces atherosclerotic lesion development in apolipoprotein E-deficient mice. Proc Natl Acad Sci USA 1996;93:100227.

38 Paech K, Webb P, Kuiper GG, et al. Differential ligand activation of estrogen receptors ERalpha and ERbeta at AP1 sites. Science 1997;277:1508-10. 